\title{
DEFOLIATION DYNAMICS OF Brachiaria brizantha PASTURES WITH DISTINCT STRUCTURAL CHARACTERISTICS
}

\author{
DINÂMICA DE DESFOLHAÇÃO EM PASTOS DE Brachiaria brizantha COM \\ CARACTERÍSTICAS ESTRUTURAIS DISTINTAS
}

\author{
Patrick Bezerra FERNANDES ${ }^{1,2} *$; Rodrigo Amorim BARBOSA ${ }^{3}$; \\ Raísa Turcato de OLIVEIRA ${ }^{1}$; Caio Vinicio Vargas de OLIVEIRA ${ }^{1}$; \\ Cauby de MEDEIROS-NETO ${ }^{4}$
}

1. Mestrado em Zootecnia, Instituto Federal de Educação, Ciência e Tecnologia Goiano - Campus Rio Verde, GO, Brasil. zoo.patrick@hotmail.com; 2. Bolsista da Fundação de Amparo a Pesquisa do Estado de Goiás-FAPEG, GO, Brasil; 3. Pesquisador, Empresa Brasileira de Pesquisa Agropecuária - Centro Nacional de Pesquisa em Gado de Corte. rodrigo.barbosa@embrapa.br; 4. Doutor, Ciência Animal, Universidade do Estado de Santa Catarina, SC, Brasil.

\begin{abstract}
Although belonging to the same species, different Brachiaria brizantha varieties used for pasture vary significantly in their morphological structure. Therefore, this study starts from the central hypothesis that the defoliation dynamics during the period of occupation by animals in pastures formed by Brachiaria brizantha under rotational stocking varies among cultivars during the year. The experimental design used was randomized blocks with three treatments and three repetitions, with the cultivars consisting of Brachiaria brizantha cv. Xaraés, BRS Paiaguás, and Ecótipo B4. The defoliation patterns during the grazing periods were estimated using the marked tiller technique. Despite alterations in the tiller and forage mass components in the wet and dry seasons, no variations were observed in the tiller defoliation dynamics and the respective structural components. In the wet season, the area grazed only once was greater for BRS Paiaguás compared to the other two cultivars, but the other areas representing the grazing horizons were equally exploited among the grass varieties during the year. Therefore, based on the defoliation dynamics of pastures in Brazil's tropical climate, it is possible to suggest that pastures formed by grasses with different structures and growth habits can be submitted to similar management strategies without impairing the forage canopy exploitation by the animals.
\end{abstract}

KEYWORDS: Defoliation severity. Grazing frequency. Leaf area index. Rotational stocking.

\section{INTRODUCTION}

Information on the structural components of the forage canopy is essential to establish pasture management strategies since during the occupation period in rotational stocking the animals tend to develop defoliation strategies that reduce the forage mass and canopy height (HODGSON, 1990).

Therefore, understanding the defoliation dynamics at the tiller level and the respective components of grasses, especially in tropical climates, can contribute to the establishment of management goals (LEMAIRE et al., 2009; MAZZANTI; LEMAIRE, 1994).

Also, climate fluctuations during the year and grasses with different structures can cause variations in the morphological components, which in turn alter the patterns of pasture exploitation, influencing the removal of herbage (CARVALHO, 2013). These observations lead to the following hypothesis: structural variations in Brachiaria brizantha pastures (EUCLIDES et al., 2008; LARA;
PEDREIRA, 2011) can modify the grass defoliation dynamics during the year.

Therefore, the objective of this study was to assess the defoliation dynamics during the occupation of pastures formed of three Brachiaria brizantha cultivars under rotational stocking during the year.

\section{MATERIAL AND METHODS}

The experiment was conducted at the research farm of the Embrapa Gado de Corte, located in the municipality of Campo Grande, Mato Gross do Sul, Brazil $\left(20^{\circ} 27^{\prime} \mathrm{S}, 54^{\circ} 37^{\prime} \mathrm{W}\right.$, and altitude of $530 \mathrm{~m}$ ). The regional climate, according to the Köppen classification, is Aw, characterized as tropical, with a well-defined dry season during the cold months and rainy season during the summer (Figure 1). The soil in the experimental area is classified as Latossolo Vermelho distroférrico (Oxisol), with clayey texture, acidic, low base saturation, and high aluminum concentration. 


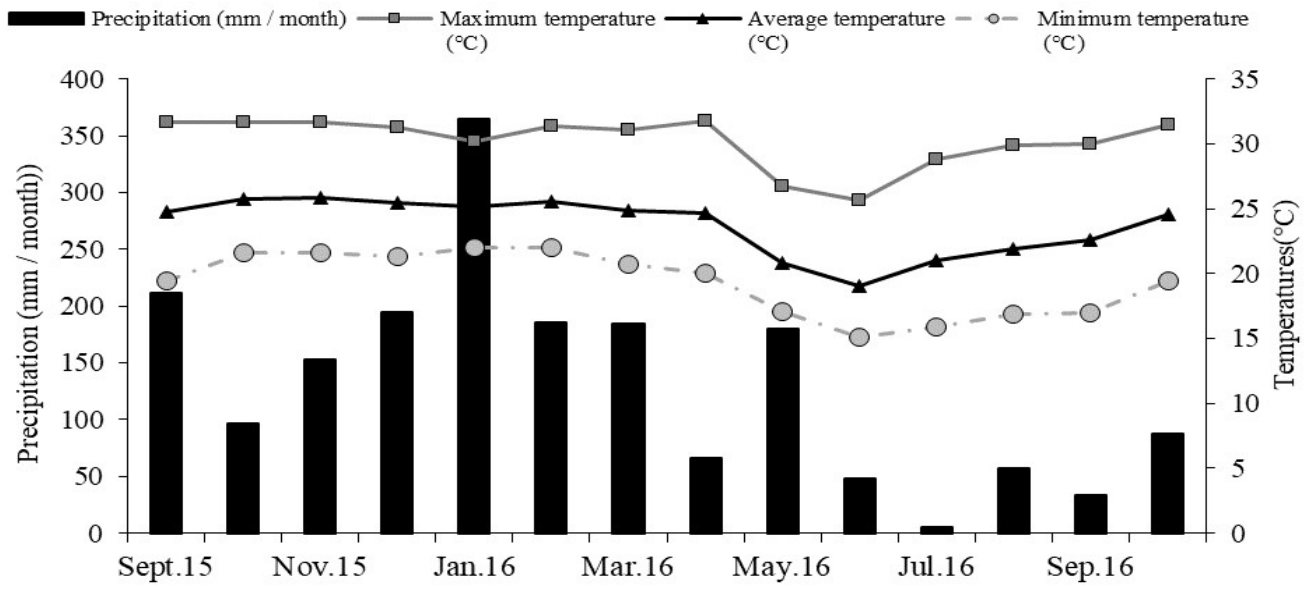

Figure 1. Mean, minimum and maximum temperatures and monthly rainfall from September 2015 to October 2016

The experimental design was randomized blocks with three treatments and three repetitions, for a total of nine experimental units (Paddocks). Each paddock was composed of an area of 1.5 hectares, equally divided into six subunits, with rotational stocking. The treatments were composed of three varieties of Brachiaria brizantha: Xaraés, BRS Paiaguás, and Ecótipo B4.

The rotational stocking regime involved grazing for 5 days followed by 25 days of rest in the wet season and 7 days of grazing followed by 35 days of rest in the dry season. The seasons were determined by the historical rainfall distribution in the region, according to which the rainy season extends from November to April and the dry season lasts from May to October (Figure 1).

Angus bullocks were used for the defoliation of the pastures. They had an average initial weight of $180 \mathrm{~kg}$ and were weighed every 30 days to estimate the stocking density of each grazing cycle.

To estimate the grass height before each grazing cycle and on each day of occupation, 30 points were randomly chosen in a sub-paddock of each paddock. The forage biomass was estimated by collecting nine samples from each paddock before each grazing cycle. For this purpose, for each sample, all the grass was cut within a square with an area of $1.0 \mathrm{~m}^{2}$. The material was placed in plastic bags, which were taken to the laboratory where the material was divided into two equal parts: half was dried in a forced-air oven at $55^{\circ} \mathrm{C}$ until reaching constant weight and the other half was separated into its botanical components (Leaf blade, pseudostem, and senescent material) and then each component was dried at $55{ }^{\circ} \mathrm{C}$ until reaching constant weight.

A total of 300 green leaf blades were collected, 100 of each cultivar, to measure the leaf area $\left(\mathrm{LA}, \mathrm{cm}^{2}\right)$. The tiller population density (TPD $\mathrm{m}^{-2}$ ) was estimated by placing three square frames with an area of $1.0 \mathrm{~m}^{2}$ randomly in each subpaddock before the grazing cycle. The number of tillers within each frame was recorded to calculate the average for each treatment. This enabled calculating the leaf area index (LAI), according to the formula LAI $=($ LA $x$ TPD $) /$ ground area (Adapted from GASTAL; LEMAIRE, 2015).

The defoliation patterns during the grazing periods were estimated using the marked tiller technique (HODGSON, 1966). For this purpose, 45 tillers were chosen per treatment, 15 per repetition, distributed on three rulers ( 5 tillers per ruler). Each ruler was allocated randomly in the sub-paddock, and the tillers were allocated every $1.0 \mathrm{~m}$ of distance.

The tillers were identified using colored plastic rings to facilitate their location. All the leaves of each marked tiller were measured and classified concerning the following characteristics: (a) leaf blade length; (b) intact or defoliated; (c) undergoing expansion or already expanded; and (d) senescent. Besides this, the length of the pseudostems was recorded, considered to be the distance between the soil and the ligula of the last completely expanded leaf, and they were classified as intact or defoliated. The analysis of the tillers described above was performed in the morning during all days the sub-paddocks were occupied by animals.

The defoliation frequency was measured according to the following formula: defoliation frequency $=$ number of defoliations per tiller/(Number of tillers marked $\times$ duration of the assessment). In turn, the defoliation severity (Herbage removed in each defoliation event) was 
determined by the following formula: defoliation severity $=($ Initial length - final length $) /$ initial length.

The totally grazed area (TGA) was calculated by quantifying the defoliated tillers during the assessment period about the number of marked tillers, using the following formula: TGA = number of defoliated tillers/number of marked tillers. To ascertain the exploitation of the different grazed horizons during the occupation period, we considered successive defoliations in which a single tiller was related to the grazing in its horizons. The area grazed only once (AG1x) referred to the percentage of grazing of the first horizon: $A G 1 x=$ number of tillers defoliated once/number of tillers defoliated; the area grazed twice (AG2x) was the percentage of grazing of the second horizon: AG2x $=$ number of tillers defoliated twice/number of tillers defoliated; the area grazed three times (AG3x) was the percentage of grazing of the third horizon: AG3x $=$ number of tillers defoliated three times/number of tillers defoliated; the area grazed four times (AG4x) was the percentage of grazing of the fourth horizon: $\mathrm{AG} 4 \mathrm{x}=$ number of tillers defoliated four times/number of tillers defoliated; and, the area grazed five times (AG5x) was the percentage of grazing of the fifth horizon: AG5x = number of tillers defoliated five times/number of tillers defoliated (Adapted from BAUMONT et al., 2004).

The data were submitted to analysis of variance for each season of the year (Wet season: November 13, 2015, to May 5, 2016; dry season: July 11, 2016, to August 31, 2016), in addition to having been considered the interaction between seasons and Brachiaria brizantha varieties. The means were compared by the Tukey test at 5\% significance level, using the $\mathrm{R}$ program version 3.0.3 (R CORE TEAM, 2014).

\section{RESULTS AND DISCUSSION}

The number of leaf blade (NLB), leaf blade length (LBL), stem+pseudostem height (SH), tiller population density (TPD), leaf area index (LAI), forage canopy height, forage mass (FM), leaf blade mass (LBM), pseudostem mass (PSM), dead matter mass (DMM), forage volumetric density (FVD) and stocking rate (SR) were estimated to characterize the differences in the forage canopies of the pastures formed by the three Brachiaria brizantha varieties during the wet and dry seasons (Table 1).

Table 1. Characteristics of the pastures according to the growing season.

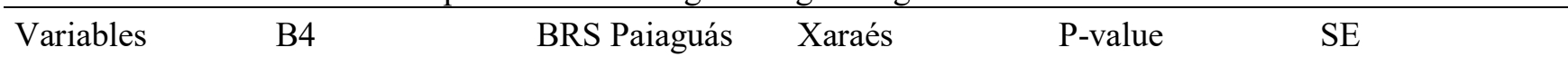

Wet season

Structural components of the forage canopy

$\begin{array}{llllll}\text { NLB } & 2.92^{\mathrm{a}} & 2.71^{\mathrm{a}} & 3.13^{\mathrm{a}} & 0.285 & 0.026 \\ \text { LBL } & 32.00^{\mathrm{a}} & 19.76^{\mathrm{c}} & 26.61^{\mathrm{b}} & 0.001 & 1.07 \\ \text { SH } & 32.59^{\mathrm{a}} & 21.82^{\mathrm{b}} & 30.16^{\mathrm{ab}} & 0.011 & 1.55 \\ \text { TPD } & 192.80^{\mathrm{b}} & 418.20^{\mathrm{a}} & 257.73^{\mathrm{b}} & 0.001 & 17.63 \\ \text { Before grazing } & & & & & \\ \text { LAI } & 3.00^{\mathrm{a}} & 2.58^{\mathrm{a}} & 3.04^{\mathrm{a}} & 0.204 & 0.117 \\ \text { Height } & 70.70^{\mathrm{a}} & 42.9^{\mathrm{b}} & 63.92^{\mathrm{a}} & 0.001 & 1.07 \\ \text { FM } & 3760.60^{\mathrm{a}} & 2664.54^{\mathrm{b}} & 3403.22^{\mathrm{a}} & 0.001 & 131.25 \\ \text { LBM } & 1872.26^{\mathrm{a}} & 1240.56^{\mathrm{a}} & 1668.56^{\mathrm{a}} & 0.113 & 124.96 \\ \text { PSM } & 1018.00^{\mathrm{a}} & 659.09^{\mathrm{b}} & 972.22^{\mathrm{a}} & 0.001 & 42.59 \\ \text { DMM } & 870.34^{\mathrm{a}} & 764.89^{\mathrm{a}} & 762.44^{\mathrm{a}} & 0.667 & 54.54 \\ \text { FVD } & 19.49^{\mathrm{a}} & 16.63^{\mathrm{a}} & 19.59^{\mathrm{a}} & 0.213 & 0.763\end{array}$

Animal component

SR

$4.64^{\mathrm{a}}$

$4.16^{\mathrm{a}}$

$4.86^{\mathrm{a}}$

0.052

0.488

Dry season

Structural components of the forage canopy
NLB
$3.73^{\mathrm{a}}$
$2.81^{\mathrm{a}}$
$2.45^{\mathrm{a}}$
0.088
0.259 


$\begin{array}{llllll}\text { LBL } & 20.7^{\mathrm{a}} & 14.46^{\mathrm{ab}} & 13.33^{\mathrm{b}} & 0.024 & 1.22 \\ \text { SH } & 20.41^{\mathrm{a}} & 19.98^{\mathrm{a}} & 17.96^{\mathrm{a}} & 0.495 & 0.942 \\ \text { TPD } & 188.16^{\mathrm{b}} & 320.66^{\mathrm{a}} & 190.00^{\mathrm{b}} & 0.001 & 17.96 \\ \text { Before grazing } & & & & \\ \text { LAI } & 1.36^{\mathrm{a}} & 0.943^{\mathrm{a}} & 0.941^{\mathrm{a}} & 0.121 & 0.092 \\ \text { Height } & 37.33^{\mathrm{a}} & 32.46^{\mathrm{a}} & 39.65^{\mathrm{a}} & 0.160 & 1.64 \\ \text { FM } & 3132.81^{\mathrm{a}} & 2632.96^{\mathrm{a}} & 3296.85^{\mathrm{a}} & 0.315 & 185.07 \\ \text { LBM } & 775.56^{\mathrm{a}} & 748.76^{\mathrm{a}} & 649.90^{\mathrm{a}} & 0.717 & 61.29 \\ \text { PSM } & 855.28^{\mathrm{a}} & 726.31^{\mathrm{a}} & 567.30^{\mathrm{a}} & 0.173 & 62.96 \\ \text { DMM } & 1501.90^{\mathrm{ab}} & 1157.90^{\mathrm{b}} & 2079.66^{\mathrm{a}} & 0.043 & 153.22 \\ \text { FVD } & 12.80^{\mathrm{a}} & 12.42^{\mathrm{a}} & 12.62^{\mathrm{a}} & 0.981 & 0.703 \\ \text { Animal component } & & & & 0.206 \\ \text { SR } & 1.17^{\mathrm{b}} & 1.93^{\mathrm{a}} & 1.93^{\mathrm{a}} & 0.001 & \end{array}$

Means followed by same lowercase letters in the row do not differ by the Tukey test at $5 \%$ probability level. P-value: probability of significant effect by the F-test; number of leaf blades (NLB); leaf blade length (LBL cm), stem height (SH, $\mathrm{cm}$ ), tiller population density $\left(\mathrm{TPD}, \mathrm{m}^{-2}\right)$, leaf area index (LAI), forage canopy height $(\mathrm{cm})$, forage mass (FM: $\left.\mathrm{kg} \mathrm{DM} \mathrm{ha}^{-1}\right)$, leaf blade mass (LBM: $\left.\mathrm{kg} \mathrm{DM} \mathrm{ha}^{-1}\right)$, pseudostem mass (PSM, $\mathrm{kg} \mathrm{DM} \mathrm{ha}{ }^{-1}$ ), dead matter mass (DMM, $\mathrm{kg} \mathrm{DM} \mathrm{ha}^{-1}$ ), forage volumetric density $\left(\mathrm{FVD}^{\mathrm{g}} \mathrm{g} \mathrm{cm}^{-1}\right)$ and stocking rate (SR, animals ha ${ }^{-1}$ ). The standard error (SE).

The climate variations in tropical regions affect the formation of pastures during the year. During the wet season, the increased flow in the plant tissues accelerates the appearance and growth of the tissues, while in the dry season these processes are reduced and the accumulation of senescent matter is usually greater (LARA; PEDREIRA, 2011; SBRISSIA; SILVA, 2008). The structural alterations, in turn, can generate different impacts on the defoliation dynamics by livestock, and consequently on animal performance (BRISKE et al., 2008; CHIRAT et al., 2014; DA SILVA et al., 2013; HIRATA et al., 2015; ROMERA et al., 2012).

During the wet season, structural components such as canopy height, LBL, SH, and TPD presented variation according to the Brachiaria brizantha pastures (Table 1). These structural differences suggest alterations both in the vertical and horizontal distribution of the materials evaluated (BENVENUTTI et al., 2008; BENVENUTTI et al., 2009).

For the variables of defoliation dynamics, no interaction was observed between Brachiaria brizantha and year seasons $(P>0.05)$. Therefore, the results and discussion will be divided into two segments, the wet and the dry season.

Despite the structural contrast of the three grass cultivars, no differences were observed in the defoliation severity during the wet season (Table 2). According to Benvenutti et al. (2008), this variable can be influenced by the physical barrier formed by the presence of stems. Despite the differences observed in the canopy height and stem height (Table 1), the ratio between the mass of these two components remained the same (About 48\%), possibly having a similar influence on the defoliation severity of the materials evaluated. This result can also be explained by the similarity of the forage volumetric density since the defoliation severity in each mouthful is intrinsically related to the forage density along with the vertical profile of the canopy (BENVENUTTI et al., 2008).

The different structures formed by the three grass varieties did not influence the tiller defoliation frequency and structural components during the wet season (Table 3). According to Hodgson (1990), the defoliation frequency is defined as the number of defoliation events to which a tiller or its components is subjected during a determined time period, and in rotational stocking it is possible for a single component to be defoliated more than once during the occupation period, because the animals exploit different structures over the grazing horizons (BAUMONT et al., 2004; MEZZALIRA et al., 2014), as observed in Table 3. 
Table 2. Defoliation severity by tiller structural component according to the growing season.

\begin{tabular}{llllll}
\hline Component & B4 & BRS Paiaguás & Xaraés & P-value & SE \\
\hline Wet season & & & & & \\
Extended tiller & $0.378^{\mathrm{a}}$ & $0.375^{\mathrm{a}}$ & $0.292^{\mathrm{a}}$ & 0.091 & 0.018 \\
Leaf blade & $0.690^{\mathrm{a}}$ & $0.715^{\mathrm{a}}$ & $0.571^{\mathrm{a}}$ & 0.091 & 0.028 \\
Expansion & $0.793^{\mathrm{ab}}$ & $0.840^{\mathrm{a}}$ & $0.703^{\mathrm{b}}$ & 0.002 & 0.017 \\
Expanded & $0.760^{\mathrm{a}}$ & $0.769^{\mathrm{a}}$ & $0.686^{\mathrm{a}}$ & 0.156 & 0.019 \\
Senescent & $0.516^{\mathrm{a}}$ & $0.537^{\mathrm{a}}$ & $0.323^{\mathrm{a}}$ & 0.371 & 0.067 \\
Pseudostem & $0.232^{\mathrm{a}}$ & $0.271^{\mathrm{a}}$ & $0.260^{\mathrm{a}}$ & 0.274 & 0.011 \\
Dry season & & & & & \\
Extended tiller & $0.394^{\mathrm{a}}$ & $0.348^{\mathrm{a}}$ & $0.435^{\mathrm{a}}$ & 0.496 & 0.032 \\
Leaf blade & $0.870^{\mathrm{a}}$ & $0.863^{\mathrm{a}}$ & $0.776^{\mathrm{a}}$ & 0.356 & 0.037 \\
Expansion & $0.864^{\mathrm{a}}$ & $0.931^{\mathrm{a}}$ & $0.872^{\mathrm{a}}$ & 0.078 & 0.016 \\
Expanded & $0.877^{\mathrm{a}}$ & $0.916^{\mathrm{a}}$ & $0.839^{\mathrm{a}}$ & 0.281 & 0.020 \\
Senescent & $0.871^{\mathrm{a}}$ & $0.742^{\mathrm{a}}$ & $0.617^{\mathrm{a}}$ & 0.304 & 0.085 \\
Pseudostem & $0.233^{\mathrm{b}}$ & $0.394^{\mathrm{a}}$ & $0.296^{\mathrm{ab}}$ & 0.033 & 0.025 \\
\hline M & & & & & \\
\hline
\end{tabular}

Means followed by same lowercase letters in the row do not differ by the Tukey test at 5\% probability. P-value: the probability of significant effect by the F-test. The standard error (SE).

Table 3. Defoliation frequency per tiller and structural component of the tillers according to the growing season.

\begin{tabular}{llllll}
\hline Component & B4 & BRS Paiaguás & Xaraés & P-value & SE \\
\hline Wet season & & & & & \\
Tiller & $0.493^{\mathrm{a}}$ & $0.492^{\mathrm{a}}$ & $0.532^{\mathrm{a}}$ & 0.536 & 0.016 \\
Expansion & $0.193^{\mathrm{a}}$ & $0.208^{\mathrm{a}}$ & $0.213^{\mathrm{a}}$ & 0.445 & 0.007 \\
Expanded & $0.173^{\mathrm{a}}$ & $0.175^{\mathrm{a}}$ & $0.184^{\mathrm{a}}$ & 0.799 & 0.007 \\
Senescent & $0.024^{\mathrm{a}}$ & $0.026^{\mathrm{a}}$ & $0.024^{\mathrm{a}}$ & 0.973 & 0.004 \\
Pseudostem & $0.171^{\mathrm{a}}$ & $0.155^{\mathrm{a}}$ & $0.140^{\mathrm{a}}$ & 0.547 & 0.011 \\
Dry season & & & & \\
Tiller & $0.366^{\mathrm{a}}$ & $0.286^{\mathrm{a}}$ & $0.319^{\mathrm{a}}$ & 0.158 & 0.023 \\
Expansion & $0.127^{\mathrm{a}}$ & $0.114^{\mathrm{a}}$ & $0.123^{\mathrm{a}}$ & 0.622 & 0.006 \\
Expanded & $0.096^{\mathrm{a}}$ & $0.094^{\mathrm{a}}$ & $0.098^{\mathrm{a}}$ & 0.961 & 0.005 \\
Senescent & $0.035^{\mathrm{a}}$ & $0.031^{\mathrm{a}}$ & $0.023^{\mathrm{a}}$ & 0.680 & 0.005 \\
Pseudostem & $0.091^{\mathrm{a}}$ & $0.091^{\mathrm{a}}$ & $0.091^{\mathrm{a}}$ & 0.997 & 0.010 \\
\hline
\end{tabular}

Means followed by same lowercase letters in the row do not differ by the Tukey test at 5\% probability. P-value: the probability of significant effect by the F-test. The standard error (SE).

The reason the different structures of the forage canopy before grazing and during the grazing horizons did not influence the defoliation frequency of the three grass varieties (Table 3). It is possibly the same stocking rate utilized since according to Wade (1991), the defoliation frequency is directly related to the stocking density, irrespective of the grazing system. Also, according to that author, the defoliation frequency can be used to estimate the percentage of the area grazed.

Independently of the structures formed by the different grasses, the form of exploitation of the totally grazed area was relatively constant in the wet season (Table 4). In contrast, the area grazed only once (Grazed only in the upper horizon of the canopy) was greater for BRS Paiaguás than for Xaraés (Table 4).

This result could suggest a better quality of the diet selected by the animals in pastures formed by BRS Paiaguás since this horizon is formed mainly by mature and expanding leaves. However, this assumption must be rejected after analyzing the data on animal exploitation in other grazing horizons, which were equally exploited for the different grasses (Table 4). Besides this, there was a relatively constant trend of reduction of the LAI during the animal occupation period (Figure 2), suggesting very similar behavior in the grazing process, regardless of the structures generated by the different grasses. 
Table 4. Totally grazed area over the horizons for each season of the year in Brachiaria brizantha pastures.

\begin{tabular}{llllll}
\hline Grazed area & B4 & BRS Paiaguás & Xaraés & P-value & SE \\
\hline Wet season & & & & \\
TGA & $0.706^{\mathrm{a}}$ & $0.713^{\mathrm{a}}$ & $0.713^{\mathrm{a}}$ & 0.925 & 0.008 \\
AG1x & $0.202^{\mathrm{ab}}$ & $0.239^{\mathrm{a}}$ & $0.115^{\mathrm{b}}$ & 0.024 & 0.020 \\
AG2x & $0.326^{\mathrm{a}}$ & $0.302^{\mathrm{a}}$ & $0.351^{\mathrm{a}}$ & 0.632 & 0.021 \\
AG3x & $0.271^{\mathrm{a}}$ & $0.249^{\mathrm{a}}$ & $0.311^{\mathrm{a}}$ & 0.434 & 0.020 \\
AG4x & $0.057^{\mathrm{b}}$ & $0.130^{\mathrm{a}}$ & $0.094^{\mathrm{ab}}$ & 0.030 & 0.011 \\
AG5x & $0.035^{\mathrm{a}}$ & $0.013^{\mathrm{a}}$ & $0.035^{\mathrm{a}}$ & 0.560 & 0.010 \\
Dry season & & & & & \\
TGA & $0.733^{\mathrm{a}}$ & $0.677^{\mathrm{a}}$ & $0.711^{\mathrm{a}}$ & 0.116 & 0.011 \\
AG1x & $0.133^{\mathrm{a}}$ & $0.266^{\mathrm{a}}$ & $0.300^{\mathrm{a}}$ & 0.169 & 0.044 \\
AG2x & $0.411^{\mathrm{a}}$ & $0.489^{\mathrm{a}}$ & $0.433^{\mathrm{a}}$ & 0.627 & 0.031 \\
AG3x & $0.311^{\mathrm{a}}$ & $0.122^{\mathrm{b}}$ & $0.199^{\mathrm{Ab}}$ & 0.020 & 0.031 \\
AG4x & $0.100^{\mathrm{a}}$ & $0.055^{\mathrm{a}}$ & $0.022^{\mathrm{a}}$ & 0.193 & 0.019 \\
AG5x & $0.044^{\mathrm{a}}$ & $0.011^{\mathrm{a}}$ & $0.022^{\mathrm{a}}$ & 0.522 & 0.012 \\
\hline
\end{tabular}

Means followed by same lowercase letters in the row do not differ by the Tukey test at 5\% probability level. P-value: the probability of significant effect by the F-test. Totally grazed area (TGA); area grazed once (AG1x); area grazed twice (AG3x); area grazed three times (AG3x); area grazed four times (AG4x), and area grazed five times (AG5x). The standard error (SE).

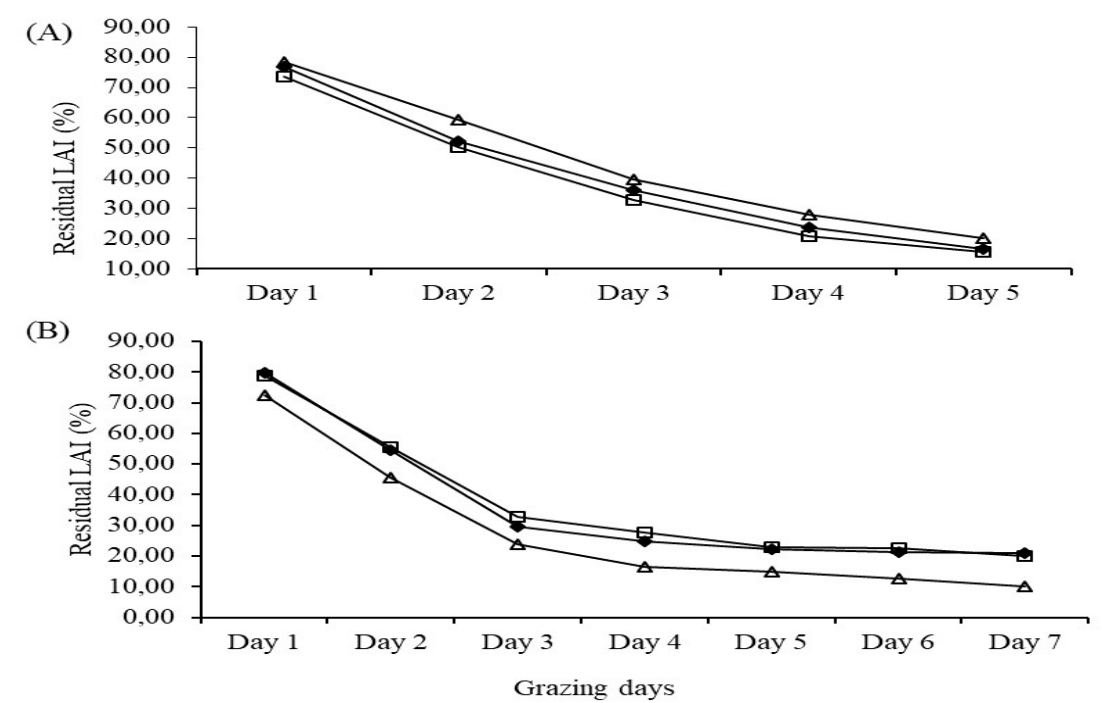

Figure 2. The ratio between days of grazing and reduction of leaf area index (LAI \%), for the wet (A) and dry (B) season. B4 $(\bullet)$, BRS Paiaguás $(\square)$ and Xaraés $(\triangle)$.

It should be noted that although the residual LAI was relatively low, the totally grazed area at the end of occupation was within the intervals recommended to maximize ingestion of forage and animal performance by Baumont et al. (2004) and Fonseca et al. (2012), which is between 70 to $85 \%$ of the total area (Table 4).

During the dry season, the forage mass and canopy height before grazing were similar for the three grass varieties, with average values of 3,020 $\mathrm{kg}$ and $36 \mathrm{~cm}$, respectively. Variations in the LBL and TPD suggest the existence of adjustment mechanisms for maintenance of the forage mass in this season (Table 1). This similarity among the structures of the pastures during the dry season is possibly associated with the reduction of the forage growth rate, independent of the cultivar, resulting from the water shortage observed during this season (BARBOSA et al., 2011; EUCLIDES et al., 2008).

No variation was observed in the defoliation severity of extended tillers, leaf blades and their respective categories (Table 2), which can be associated with the fact the forage volumetric density was the same for the different grasses. On the other hand, BRS Paiaguás pastures presented greater defoliation severity of the pseudostems about Ecotype B4. Generally, pastures with higher TPD produce lighter tillers with lower specific weight (SBRISSIA; SILVA, 2008), suggesting greater defoliation facility of this component. Besides this, pastures of Xaraés and B4, which have an erect growth habit, lower TPD and tillers with 
higher specific weight, can form physical barriers to the bite depth of the animals (BARBOSA et al., 2007; CARNEVALLI et al., 2006; PEREIRA et al., 2014; ROMERA et al., 2012; ZANINI et al., 2012).

The defoliation frequency of tillers and their structural components was similar for the cultivars (Table 3), despite the differences in the animal stocking densities (Table 1). Therefore, the similarity of the defoliation frequency during the dry season appears to have been more related to the characteristics of the canopy than the stocking density. Lemaire et al. (2009) and Mazzanti and Lemaire (1994) suggested that to detect oscillations in defoliation events, it is necessary to have variations in the structural components, mass, and density of the forage, so these characteristics possibly influenced the defoliation pattern during the dry season.

With the longer occupation period in the dry season ( 7 days), from the first to the third day of occupation there was a reduction of 70 to $75 \%$ of the LAI in the pastures. Besides this, as of the moment the residual LAI reached 25 to $30 \%$, no severe defoliation was observed until the last day of occupation. This suggests limitations in the grazing, probably due to the greater participation of pseudostem mass and senescent material in the total biomass.
On the other hand, the totally grazed area during the dry season was approximately $70 \%$, regardless of the grass (Table 4). This result demonstrates that despite the management based on fixed days and restrictive conditions during the dry season, the area grazed was similar to that in the wet season and within the interval recommended for rotational stocking ( 70 to $85 \%$ of the grazed area) (UNGAR 1998; BAUMONT et al., 2004; FONSECA et al., 2012).

\section{CONCLUSION}

Based on the defoliation dynamics in pastures in areas with Brachiaria brizantha, it is possible to conclude that pastures formed by grasses with different structures and growth patterns can be submitted to similar management strategies without impairing the exploitation of the forage canopy by livestock.

\section{ACKNOWLEDGMENTS}

We thank the Instituto Federal GoianoCampus Rio Verde and Embrapa - Gado de Corte for the support of this study and FAPEG for granting the scholarship.

RESUMO: Apesar de pertencerem à mesma espécie, existem diversas variedades disponíveis no mercado de pastos de Brachiaria brizantha, os quais variam significativamente na estrutura. Assim, este trabalho partiu da hipótese central que a dinâmica de desfolhação durante o período de ocupação dos animais em pastos de Brachiaria brizantha, sob lotação rotativa, varia entre cultivares ao longo do ano. O delineamento experimental utilizado foi de blocos casualizados com três tratamentos e três repetições constituídos pelas Brachiaria brizantha cv. Xaraés, BRS Paiaguás e o ecótipo B4. Os padrões de desfolhação, durante o rebaixamento dos pastos, foram estimados utilizando a técnica de perfilhos marcados. Apesar de alterações nos componentes do perfilho e massa de forragem, na época das águas e secas, não foi observado variações na dinâmica de desfolhação de perfilho e seus respectivos componentes estruturais. No período das águas a área pastejada apenas uma vez, foi maior na BRS Paiaguás quando comparado aos demais pastos, porém as demais áreas que equivalem aos horizontes de pastejo foram igualmente exploradas entre as gramíneas durante o ano. Portanto, baseado na dinâmica de desfolhação em pastos de clima tropical, é possível sugerir que pastos formados com gramíneas com diferentes estruturas e hábitos de crescimento podem ser submetidos a semelhantes estratégias de manejo sem prejudicar o processo de exploração do dossel forrageiro pelo animal.

PALAVRAS-CHAVE: Frequência de pastejo. Índice de área foliar. Lotação rotativa. Severidade de desfolhação.

\section{REFERENCES}

BARBOSA, R. A.; NASCIMENTO JÚNIOR, D. D.; EUCLIDES, V. P. B.; SILVA, S. D.; ZIMMER, A. H.; TORRES JÚNIOR, R. D. A. Capim-tanzânia submetido a combinações entre intensidade e freqüência de pastejo. Pesquisa Agropecuária Brasileira, v. 42, n. 3, p. 329-340, 2007. https://doi.org/10.1590/S0100204X2007000300005 
BARBOSA, R. A.; NASCIMENTO JÚNIOR, D. D.; VILELA, H. H., SILVA, S. C. D.; EUCLIDES, V. P. B.; SBRISSIA, A. F.; SOUSA, B. M. D. L. Morphogenic and structural characteristics of guinea grass pastures submitted to three frequencies and two defoliation severities. Revista Brasileira de Zootecnia, v. 40, n. 5, p. 947-954, 2011. http://dx.doi.org/10.1590/S1516-35982011000500002

BAUMONT, R.; COHEN-SALMON, D.; PRACHE, S.; SAUVANT, D. A mechanistic model of intake and grazing behaviour in sheep integrating sward architecture and animal decisions. Animal Feed Science and Technology, v. 112, n. 1, p. 5-28, 2004. https://doi.org/10.1016/j.anifeedsci.2003.10.005.

BENVENUTTI, M. A.; GORDON, I. J.; POPPI, D. P.; CROWTHER, R.; SPINKS, W. Foraging mechanics and their outcomes for cattle grazing reproductive tropical swards. Applied Animal Behaviour Science, v. 113, n. 1, p. 15-31, 2008. https://doi.org/10.1016/j.applanim.2007.10.005

BENVENUTTI, M. A.; GORDON, I. J.; POPPI, D. P.; CROWTHER, R.; SPINKS, W.; MORENO, F. C. The horizontal barrier effect of stems on the foraging behaviour of cattle grazing five tropical grasses. Livestock Science, v. 126, n. 1, p. 229-238, 2009. https://doi.org/10.1016/j.livsci.2009.07.006

BRISKE, D. D.; DERNER, J. D.; BROWN, J. R.; FUHLENDORF, S. D.; TEAGUE, W. R.; HAVSTAD, K. M.; WILLMS, W. D. Rotational grazing on rangelands: reconciliation of perception and experimental evidence. Rangeland Ecology \& Management, v. 61, n. 1, p. 3-17, 2008. https://doi.org/10.2111/06-159R.1

CARNEVAlli, R. A.; DA SILVA, S. C.; BUENO, A. A. O.; UEBELE, M. C.; HODGSON, J.; SILVA, G. N.; MORAIS, J. P. G. Herbage production and grazing losses in Panicum maximum cv. Mombaça under four grazing managements. Tropical Grasslands, v.40, p.165-176, 2006.

CARVALHO, P. C. F. Harry Stobbs Memorial Lecture: Can grazing behavior support innovations in grassland management?. Tropical Grasslands-Forrajes Tropicales, v. 1, n. 2, p. 137-155, 2013. https://doi.org/10.17138/TGFT(1)137-155

CHIRAT, G.; GROOT, J. C.; MESSAD, S.; BOCQUIER, F.; ICKOWICZ, A. Instantaneous intake rate of free-grazing cattle as affected by herbage characteristics in heterogeneous tropical agro-pastoral landscapes. Applied Animal Behaviour Science, v. 157, p. 48-60, 2014. https://doi.org/10.1016/j.applanim.2014.06.003

DA SILVA, S. C.; GIMENES, F. M. A.; SARMENTO, D. O. L.; SBRISSIA, A. F.; OLIVEIRA, D. E.; HERNADEZ-GARAY. A.; PIRES, A.V. Grazing behaviour, herbage intake and animal performance of beef cattle heifers on marandu palisade grass subjected to intensities of continuous stocking management. The Journal of Agricultural Science, v. 151, n. 05, p. 727-739, 2013. https://doi.org/10.1017/S0021859612000858

EUCLIDES, V. P. B.; MACEDO, M. C. M.; DO VALle, C. B.; BARBOSA, R. A.; GONÇALVES, W. V. Produção de forragem e características da estrutura do dossel de cultivares de Brachiaria brizantha sob pastejo. Pesquisa Agropecuária Brasileira, v. 43, n. 12, p. 1805-1812, 2008. https://doi.org/10.1590/S0100204X2008001200023

FONSECA, L.; MEZZALIRA, J. C.; BREMM, C.; CARVALHO, P. C. F. Grazing by horizon: what would be the limits to maintain maximum short-term herbage intake rate? Grassland Science in Europe, v. 17, p. 237239, 2012.

GASTAL, F; LEMAIRE, G. Defoliation, shoot plasticity, sward structure and herbage utilization in pasture: Review of the underlying ecophysiological processes. Agriculture, v. 5, n. 4, p. 1146-1171, 2015. https://doi.org/10.3390/agriculture5041146

HIRATA, M.; MATSUMOTO, Y.; IZUMI, S.; SOGA, Y.; HIROTA, F.; TOBISA, M. Seasonal and interannual variations in feeding station behavior of cattle: effects of sward and meteorological conditions. Animal, v. 9, n. 04, p. 682-690, 2015. DOI. https://doi.org/10.1017 / S1751731114002869 
HODGSON, J. The frequency of defoliation of individual tillers in a set stocked sward. Journal of the British Grassland Society, v. 21, p. 258-263, 1966. https://doi.org/10.1111/j.1365-2494.1966.tb00483.x

HODGSON, John. Grazing management. Science into practice. Longman Group UK Ltd., 1990.

LARA, M. A. S.; PEDREIRA, C. G. S. Respostas morfogênicas e estruturais de dosséis de espécies de Braquiária à intensidade de desfolhação. Pesquisa Agropecuária Brasileira, v. 46, n. 7, p. 760-767, 2011. http://dx.doi.org/10.1590/S0100-204X2011000700012

LEMAIRE, G.; DA SILVA, S. C.; AGNUSDEI, M.; WADE, M.; HODGSON, J. Interactions between leaf lifespan and defoliation frequency in temperate and tropical pastures: a review. Grass and Forage Science, v. 64, n. 4, p. 341-353, 2009. https://doi.org/10.1111/j.1365-2494.2009.00707.x

MAZZANTI, A.; LEMAIRE, G. Effect of nitrogen fertilization on herbage production of tall fescue swards continuously grazed by sheep. 2. Consumption and efficiency of herbage utilization. Grass and forage Science, v. 49, n. 3, p. 352-359, 1994. https://doi.org/10.1111/j.1365-2494.1994.tb02010.x

MEZZALIRA, J. C.; CARVALHO, P. C. D. F.; FONSECA, L.; BREMM, C.; CANGIANO, C.; GONDA, H. L.; LACA, E. A. Behavioural mechanisms of intake rate by heifers grazing swards of contrasting structures. Applied Animal Behaviour Science, v. 153, p. 1-9, 2014.

https://doi.org/10.1016/j.applanim.2013.12.014.

PEREIRA, L. E. T.; PAIVA, A. J.; GEREMIA, E. V.; DA SILVA, S. C. Components of herbage accumulation in elephant grass cv. Napier subjected to strategies of intermittent stocking management. Journal of Agricultural Science, v. 152, p. 954-966, 2014. https://doi.org/10.1017/S0021859613000695.

R CORE TEAM. R: A language and environment for statistical computing. R Foundation for Statistical Computing, Vienna, Austria, 2014.

ROMERA, A.J.; BURGES, J.C.; GREGORINI, P.; AGNUSDEI, M.G. Morphological components of Thynopirum ponticum tillers and their contribution to the diet of cattle grazing at contrasting herbage allowances. Livestock Science, v. 150, n. 1, p. 284-292, 2012. https://doi.org/10.1016/j.livsci.2012.09.013

SBRISSIA, A. F.; SILVA, S. C. D. Compensação tamanho/densidade populacional de perfilhos em pastos de capim-marandu. Revista Brasileira de Zootecnia, v. 37, n. 1, p. 35-47, 2008. DOI:

http://dx.doi.org/10.1590/S1516-35982008000100005

UNGAR, E. D. Changes in bite area and bite depth during patch depletion by cattle. In: GIBB, M. J. (Ed.), European Intake Workshop on Techniques for Investigating Intake and Ingestive Behaviour by Farm Animals, vol. 10, 1998, North Wyke. Proceedings. .. North Wyke, 1998. p. 81-82.

WADE, M. H. Factors affecting the availability of vegetative Lollium perenne to grazing dairy cows with special reference to sward characteristics, stocking rate and grazing method. 1991. $70 \mathrm{p}$. Thesis (Doctor in Biology Science) - University of Rennes, Rennes, 1991.

ZANINI, G. D.; SANTOS, G. T.; SBRISSIA, A. F. Frequencies and intensities of defoliation in Aruana Guineagrass swards: accumulation and morphological composition of forage. Revista Brasileira de Zootecnia, v.41, p.905-913, 2012. http://dx.doi.org/10.1590/S1516-35982012000400011 